\title{
EMPLOYMENT STATUS IN AMATEUR SPORT IN ITALY
}

\author{
Roberto CARMinA*
}

\begin{abstract}
This paper examines the social status of amateur athletes in respect of discrimination they may encounter in comparison with professional athletes. It also addresses the issue of the Italian 'vincolo sportivo' and correlative violations of EU law on the free movement of workers. Finally, some possible solutions are proposed.
\end{abstract}

Keywords: amateur athletes; discrimination; European labour law; European sports law; EU law on the free movement of workers; health care protection; Italian 'vincolo sportivo'; social status

\section{INTRODUCTION}

More than twenty years after the Bosman case ${ }^{1}$ employment law and sports still make a difficult combination. The purpose of this article is to present an ongoing debate in Italy regarding the relationship between professional sport, amateur sport and employment protection.

* Roberto Carmina, Attorney, Doctoral Candidate at the University of Palermo, Italy.

1 Court of Justice of the European Communities, 15 December 1995, C-415/93, ASBL Union Royale Belge des Sociétes de Football Association, Royal Club Liegeois, Unione des Associations Européennes de Football UEFA v. Bosman, European Court Reports 1995 I-04921. In connection with this decision of the Court of Justice of the European Communities, see, among others, M. Coccia and C. Nizzo, 'Il dopo Bosman e il modello sportivo europeo', Rivista di diritto sportivo 1998, 335; M. Di Filippo, 'La libera circolazione dei calciatori professionisti alla luce della sentenza Bosman', Rivista italiana di diritto del lavoro 1996, 232; L. Angelini, 'La libertà di circolazione dei calciatori professionisti dopo la sentenza Bosman e gli effetti nell'ordinamento italiano', Lavoro e diritto 1997, 625; S. R. Weatherill, 'Bosman changed everything: the rise of EC Sports Law', in M. Poiares Maduro and L. Azoulai (eds.), The past and future of EU Law: the classics of EU law revisited on the 50th anniversary of the Rome Treaty, Oxford, Hart Publishing, 2010, 480; J. Anderson, Modern Sports Law, Oxford, Hart Publishing, 2010, 320; J.M. Fernandez Martin, 'Free movement of workers and social security, re defining obstacles to the free movement of workers', European Law Review, 1996, 513. 
The distinction between amateur sport and professional sport, in Italy, is not very clear. ${ }^{2}$ Amateur sport in Italy is not only recreational, it also includes competitive sports played at a high level. In theory, in amateur sport, participants do not receive remuneration, while in professional sports athletes are paid for their performance.

However, in Italy, many participants in amateur sport are paid, and should thus be considered as professionals. Nevertheless, Italian sports federations do not qualify all paid sport participants as professionals. Sports federations explicitly define a category of professional sport participants, but this category is quite limited and does not include all paid performers. All non-professionals are considered to be amateurs.

This problem originates from Act No. 91/1981 on professional sport activity. This Act clarifies that certain sport can be defined as professional as long as it concerns an activity which is paid and carried out in a continuous way in the disciplines regulated by CONI (Italian Olympic Committee). ${ }^{3}$ According to this Act, the distinction between amateur and professional athletes is a matter of choice of the competent sports federations in accordance with the guidelines established by CONI. However, CONI has remitted the power to formulate the criteria necessary to determine the nature of the sport to the statutory autonomy of sports federations. Thus, the qualification of the nature of sport activity depends only on the decision made by sport federations.

When a sports federation does not qualify one sport participant as professional, he is automatically regarded as an amateur. This has repercussions on the legal status of the athletes and the relevant sports organisations. This leads to a potential problem of discrimination, which can be considered as a problem with different aspects. Firstly, there is the issue of distinguishing the professional athletes and non-professional athletes as different categories in employment law. As a matter of fact, the lack of being qualified as a 'professional' athlete leads to the inapplicability of the 'sport employment contract' regulated by Act No. 91/1981 on professional sporting activity, providing for employment and social protection. Second, the question of the extent to which these sportsmen enjoy the protection of EU free movement law arises. This question is relevant in order to determine the scope of protection applicable to them. Indeed, in Italy, it is well-known that the Italian 'vincolo sportivo', provided under the rules of the sports federations, is only applicable to amateur athletes.

2 To investigate the issue of the distinction between amateur and professional sport see, ex multis, G. Allegro, 'Sport dilettantistico e rapporti di lavoro', in L. Cantamessa, G. M. Riccio and G. Sciancalepore (eds.), Lineamenti di diritto sportivo, Milano, Giuffrè, 2008, 171; A. Bellavista, 'Il lavoro sportivo professionistico e l'attività dilettantistica', Rivista giuridica del lavoro e della previdenza sociale, 1997, 521; F. Bianchi D’urso and G. Vidiri, 'La nuova disciplina del lavoro sportivo', Rivista di diritto sportivo, 1982, 2090; G. Martinelli, 'Lavoro autonomo e subordinato nell'attività dilettantistica', Rivista di diritto sportivo, 1993, 13; P. Moro, 'Questioni di diritto sportivo: casi controversi nell'attività dei dilettanti', Pordenone, Euro 92 Editrice, 1999, 5; F. Realmonte, 'L'atleta professionista e l'atleta dilettante', Rivista di diritto sportivo, 1997, 371; G. Liotta, 'La gratuità nello sport', in A. Galasso and S. Mazzarese (eds.), Il principio di gratuità, Milano, Giuffrè, 2008, 279; D. Zinnari, 'Atleti dilettanti, sportivi non professionisti?', GiustiziaSportiva.it, 2007, 23; P. TOSI, 'Sport e diritto del lavoro', Argomenti di diritto del lavoro, 2006, 721.

3 Comitato Olimpico Nazionale Italiano. 
This article addresses these issues in the light of the principles of equality under Italian Constitutional law and the EU law on the free movement of workers, in relation to the status of amateur athletes.

\section{DISCRIMINATORY ASPECTS WHEN IT COMES TO THE SOCIAL STATUS OF ATHLETES - THE INAPPLICABILITY OF THE EMPLOYMENT SPORTS CONTRACT AND THE CONSEQUENCES ON THE HEALTH CARE PROTECTION}

The professional Italian sports sector has been governed by Law No. 91/1981. ${ }^{4}$ This Act was intended to provide a regulation of the relationship between athletes, clubs and federations to which these participants are affiliated. In other words, this law focuses on the employment relationship in the context of the professional sport practice. In order to get a better understanding of this issue, a brief explanation of this particular Act may be of great importance. Article 1 of Law No. 91/1981 states that 'sporting activities shall be freely engaged in, whether individually or collectively, as a professional or as an amateur'. Article 2 of Law No. 91/1981 prescribes that the particular Act is applicable only when it comes to the professional sports sector. In fact Article 2 of Law No. 91/1981 states that 'for the purposes of the application of this act, professional sportsmen are athletes, coaches, sports and technical directors and trainers, engaged in sports activities continuously and in a remunerated way within the disciplines governed by CONI and which derive the qualification from national sports federations, according to the rules issued by the federations themselves, in compliance with the guidelines established by CONI for the distinction between amateur and professional activity'. Law No. 91/1981 also clarifies the extent to which employment law is applicable in the sports sector. In fact, for this Act, the remunerated activities of the professional athletes are ordinarily subject to a contract of employment. However, there are three exceptions in which the contract for freelance work $^{5}$ shall be utilised. This law also states that the employment relationship should be created with a written employment contract on

$4 \quad$ On the topic, see among others, M. Colucci, 'Sport and contractual stability: the Italian case', in M. Colucci, R. Blanpian and F. Hendrickx (eds.), Contractual stability in football, European Sports Law and Policy Bulletin, Bracciano (RM), Sports Law and Policy Centre, 2011, 199; M. De Cristofaro, 'Legge 23 marzo 1981, n. 91. Norme in materia di rapporti tra società e sportivi professionisti', Le nuove leggi civili commentate, 1982, 580; F. Bianchi D’urso and G. Vidiri, 'La nuova disciplina del lavoro sportivo', Rivista di diritto sportivo, 1982, 2090.

5 Ex. Art. 3 of Law No. 91 of 1981 these exceptions are: when activities are carried out in the framework of a single sporting event or of several events linked together over a brief period of time; when the athlete is not contractually bound to attend preparation or training sessions; when although the services subject to the contract are continuous in nature, they are not carried out for a longer period than eight hours per week or five days per month or thirty days per year. 
pain of nullity, and has to contain certain clauses. ${ }^{6}$ Articles 5 and 6 of this particular Act deal with expiry term of the employment contract and the reimbursement that the sports club receives for training or coaching a young athlete. Articles 7, 8 and 9 of Law No. 91/1981 concern health care protection and social security rights. The other provisions of this particular Act relate to the functioning of sports clubs and national sports federations, taxation and transitory situations.

Furthermore, the employment status in sport in Italy needs additional clarification. In theory, the sporting order can be divided into the professional and amateur sports sectors, depending on the decisions of the sports federations. Actually the sports federations recognise only few sports as professional.

However, many amateur sportsmen are paid, and should thus be considered as professionals. The jurisprudence uses a case-by-case approach to recognise an employment relationship. In particular, for the applicability of the employment contract, the judges take into account the performance of a continued and paid sporting practice by the athlete and the course of entrepreneurial activity by the relevant club. ${ }^{7}$

On this line of thought, it is possible to distinguish between three sports sectors: the professional sports sector, the professional de facto sports sector and the amateur sports sector. The provisions of Law No. 91/1981 are applicable to the professional athletes (with the correlative specific norms on the protection of health), the general employment laws are applicable to the professional de facto athletes, while the real amateurs do not have an employment relationship and commit themselves to a particular sport just for passion and not for monetary gain. ${ }^{8}$ In other terms, a professional de facto athlete, although qualified as an amateur, and although this should determine the inapplicability of an employment contract, in practice, is often bound by various legal contracts. For example, ordinary contracts of employment, contract for freelance work and atypical contracts that are similar to the sports employment contract. In case these contracts are lacking, the national courts recognise the employment relationship and the corresponding rights of the professional de facto athlete anyway. ${ }^{9}$ In this sense, the Tribunal of Pescara stated

$6 \quad$ Art. 4 of Law No. 91 of 1981.

7 Court of Cassation, tax section, 20 February 2013, n. 4152, www.iusexplorer.it; Court of Cassation, tax section, 11 December 2012, n. 22578, Giustizia Civile Mass, 2012, 1398; Court of Cassation, tax section, 12 May 2010, n. 11456, Giustizia Civile Mass, 2010, 728; Court of Cassation, tax section, 20 February 2013, n. 4147, www.grandiclienti.ilsole24ore.com.

8 The Italian doctrine creates the figure of the professional athlete de facto. On the topic, see, ex multis, F. Bianchi D'urso and G. Vidiri, 'La nuova disciplina del lavoro sportivo', Rivista di diritto sportivo 1982, 2090; G. Martinelli, 'Lavoro autonomo e subordinato nell'attività dilettantistica', Rivista di diritto sportivo 1993, 13; L. Musumarra, 'La qualificazione degli sportivi professionisti e dilettanti nella giurisprudenza comunitaria', Rivista di diritto ed economia dello sport 2005, 39; C. Zoli, 'Sul rapporto di lavoro sportivo professionistico', Giustizia civile, 1985, 2089.

9 See, among others, Tribunal of Monza, 11 June 2001, Giurisprudenza di merito 2002, 10; Tribunal of Genova, 7 June 2001, Vita Notarile 2002, 683; Court of Cassation, tax section, 20 February 2013, 
that the distinction (which is very elusive) between amateur and professional sport seems devoid of any validity, since it is not permissible to legitimise discrimination between athletes. In addition to this, the private nature of the sports federations cannot justify the application of discriminatory principles contrary to the public order, and constitute the limit for the conclusion of employment contracts. ${ }^{10}$ In this context, the Tribunal of Trento argued that an employment relationship is present in the case of paid sporting activities, even for the disciplines qualified as amateur sports, given the primacy of EU law over national law. ${ }^{11}$ Also, the Court of Justice ${ }^{12}$ and a part of the doctrine ${ }^{13}$ dedicate themselves 'to pierce[ing] the veil which is been wrapped around our eyes', ${ }^{14}$ arguing the irrelevance of the qualification of a sport (or a sector of it) as amateur, for the application of EU law. In fact, the associative relationship of a professional de facto athlete includes the basic features of an employment relationship. The regulations of a professional de facto sport provide a managerial authority over certain amateur sporting organisations, which corresponds to the duty of subjection of the athletes. This obligation for the athletes has a contractual nature ${ }^{15}$ and disciplinary elements. For example, one can take into consideration the duty of a professional de facto soccer player, established by Article 92 of the internal organisational regulations of FIGC, to follow the rules of the relevant amateur sporting club, under punishment of sanction. The rules

n. 4152, www.iusexplorer.it; Court of Cassation, 11 December 2012, n. 22578, Giustizia Civile Mass, 2012, 1398; Court of Cassation, 20 February 2013, n. 4147, www.grandiclienti.ilsole24ore.com; Court of Cassation, 12 May 2010, n. 11456, Giustizia Civile Mass, 2010, 728.

10 Tribunal of Pescara, 18 October 2001, www.grandiclienti.ilsole24ore.com.

11 Tribunal of Trento, 27 October 2008, www.grandiclienti.ilsole24ore.com.

12 See Court of Justice of the European Communities, 8 July 1998, C-9/98, Ermanno Agostini, Emanuele Agostini v. Ligue francophone de judo et disciplines associées ASBL, Ligue belge de judo ASBL, European Court Reports 1998 I-04261; Court of Justice of the European Communities, 11 April 2000, C-51/96 and C-191/97, Christelle Deliege v. Ligue Francophone de Judo et disciplines associess ASBL e a, European Court Reports 2000 I-02549. To deepen this last pronunciation, over the limits of the above discussion, see: S. Bastianon, 'Sport e diritto comunitario: la sfida continua. I casi Deliège Lehtonen', Rivista di diritto sportivo, 1998, 662; G. Adami, 'Attività sportiva professionistica o amatoriale, secondo il diritto comunitario', Il lavoro nella giurisprudenza 2001, 236.

13 See, ex multis, S. Bastianon, 'Dal calcio alla pallamano: la giurisprudenza Bosman nella pronuncia del giudice nazionale', Rivista di diritto sportivo, 1997, 864; L. Santoro, 'L'influenza del diritto comunitario in materia di distinzione tra lavoro sportivo professionistico e dilettantistico', in G. Liotta and L. Santoro (eds.), Lezioni di diritto sportivo, Milano, Giuffrè, 2013, 122.

14 F. Petrarca, Canzoniere, Milano, Mondadori, 2006, 41.

15 Compare, ex multis, R. Caprioli, L'autonomia normativa delle Federazioni sportive nazionali nel diritto privato, Napoli, Jovene, 1997, 111; M.C. Calciano, Diritto dello sport. Il sistema delle responsabilità nell'analisi giurisprudenziale, Milano, Giuffrè, 2010, 162; P. Raimondo, Elementi di diritto privato sportivo, Bologna, Giraldi Editore, 2013, 65. Contra, those who opt for the public nature of the membership, C. Frattarolo, L'ordinamento sportivo nella giurisprudenza, Milano, Giuffrè, 1995, 107; L. Cantamessa, Un tema semi-nuovo di diritto sportivo internazionale: la third party ownership (TPO), in S. Bastianon (edited by), L'Europa e lo sport. Profili giuridici, economici e sociali, Torino, Giappichelli, 2014, 123. 
to which, the above mentioned Article refers, are the technical instructions and directives, issued in order to achieve competitive purposes, which not concern only sporting performance, but also the privacy of the athlete, since he has to be in proper physical and mental condition. ${ }^{16}$ The need to respect these rules is natural in any team, a team where individual interest should be secondary to the collective objective, which is pursued under the direction of a coach and his staff. For the athletes, these instructions derive correlative obligations of obedience. In this sense, for example, the existence of duties of this kind, for the professional de facto athletes, are set out in the collective Agreement from 27 March 2008, concluded between the Italian amateur rugby league of excellence and the Association of Italian rugby. It provides, in particular, the obligation for the professional de facto athletes to observe the duties of loyalty and fair play to the organisation, to provide a full cooperation to the managers, coaches, team doctors and teammates, and to respect the rules of conduct, dictated by the company, both on and off the playing field. ${ }^{17}$ Therefore, the relationship established by the membership of a professional de facto club, is characterised by the presence of persons in a leading position, which corresponds to the duty of obedience. Consequently, it seems plausible that, in the case of an amateur in non-recreational sport, a professional de facto employment contract exists (although in practice lacks), which is expressed in an agreement or a bond. ${ }^{18}$

However, as we anticipated, it may be argued that, in practice, professional de facto athletes are still subject to somewhat different treatment when compared to professional athletes regarding their social status. ${ }^{19}$ In fact, court judgments only demonstrate the applicability of general employment law to amateur athletes, but this does not yet imply that a special 'sport employment contract' is in place.

16 In this sense, among others, Collective agreement between LIRE - Lega Italiana Rugby Eccellenza e AIR - Associazione Italiana Rugbysti of 27 March 2008, art. 7, point 4.

17 Collective agreement between L.I.R.E - Lega Italiana Rugby Eccellenza e A.I.R - Associazione Italiana Rugbysti of 27 March 2008, Art. 7, point 3.

18 Also, a part of the national legislation does not seem to give importance to the distinction between professional activities and amateur practice. For example, Art. 22, comma 5 bis of Act No. 189/2002 provides that the requirement for a residence permit for sports work, is to conduct paid sporting activity. Further, in this sense, a ruling of the Ministry of Labour and Social Policy defines a worker as the person who, regardless of the type of contract, has a job, with or without a payment, even for the only purpose of learning a trade, art or profession, except those which deal with domestic service or when the worker is a family member (Ruling of the Ministry of Labour and Social Policy, 27 March 2014, n. 8/2014, www.iusexplorer.it, on the compulsory to make the risk document for volunteers of amateur sports associations).

19 To deepen the meaning of social status take into consideration F. Hendrickx, 'The social status of the artist: a moving picture', in A. Verbeke, B. Tillemand, E.J.H. Schrage and B. Demarsin (eds.), Art \& Law, Brugge \& Oxford, Die Keure \& Hart Publishing, 2008, 102, according to which 'the concept of "social status" would refer to the legal status (...) with regard to labour and employment law as well as social security law. This includes issues of social protection, employment rights, representation and association rights'. 
A logic question would be: 'what are the implications of this different treatment (sports employment contract in comparison with an ordinary employment contract) between a professional athlete and a professional de facto athlete?' It appears that the answer could be that the professional sports Act, compared to general employment law, provides a specific and better protection for the athlete. In fact, this particular Act contains specific norms in order to safeguard the professional liberty of sportspersons. In this regard, for example, Article 4 of Law No. 91/1981 prohibits sports clubs from including 'a no competition clause' in the contract, and also underlines that clauses with pejorative terms must be replaced with those of the standard contract. In addition, the tax law qualifies as miscellaneous income the remuneration (also significant) paid to the athletes, technicians and similar figures in the amateur sports sector, and therefore exempts them from social security. ${ }^{20}$ Also in the professional sports field, Article 8 of the particular Act, obliges sports clubs to take out individual insurance policies for professional sportsmen against the risk of death and injuries which could compromise the continuation of professional sporting activities, and Article 9 of the same law provides a pension plan. These provisions are not applicable to the professional de facto sportsmen. Therefore, these differences in the treatment seem to involve a discrimination against professional de facto athletes, which appears to be unconstitutional, since Article. 38 of the Constitution ${ }^{21}$ provides for the right of workers to have guaranteed, adequate means to meet their needs, and necessities in case of old age and involuntary unemployment. ${ }^{22}$ In addition, the legal regulation of employment contract does not take into account the specific needs of the sporting profession. Instead, these needs are fulfilled by the particular Act. As a matter of fact, there are certain provisions of Law No. 91/1981 that derogate from the legal regime of the employment contract. One could think, for example, of the rules that prohibit demotion and the use of audiovisual equipment.

However, we will focus on two important differences in the treatment between the professional sports sector and professional de facto sports sector, which depends on the application of this particular Act. The first difference in the treatment, which we take into account in our next paragraph, depends from the application of the so called 'vincolo sportivo'. The second one concerns health care protection. In fact, as we anticipated, the sports employment contract is based on Act No. 91/1981 on professional sport, which excludes amateur athletes, even if they are employees, and therefore, excludes them from the specific regulation on health care protection provided in the Act. Furthermore, according to Act No. 91/1981, in conjunction with the Ministerial Decree of13 March 1995 (as amended), in order to obtain federal

\footnotetext{
20 Art. 67(1)(M) of the Income Tax Consolidation Act (Testo Unico delle Imposte sui Redditi).

21 Art. 38 of Costitution provides: 'every citizen unable to work and without the necessary means of subsistence is entitled to welfare support. Workers have the right to be assured adequate means for their needs and necessities in the case of accidents, illness, disability, old age and involuntary unemployment.'

22 In this regard, see A. De Silvestri, 'Il lavoro nello sport dilettantistico', www.giustiziasportiva.it, 2006, 27.
} 
authorisation to practice professional sporting activities, sports associations must respect specific obligations with regard to the protection of the professional athlete, such as periodic checks, a medical card and a certificate of suitability to take part in competitive sport. ${ }^{23}$ As amateur sports organisations do not have an obligation to carry out periodic checks to protect the health of their athletes, protection through health checks remains a voluntary option for the sports federations, or for the amateur sports club concerned. Also, the internal organisational regulations of FIGC (Italian Football Federation) ${ }^{24}$ stresses that the obligation to guarantee the presence of a doctor on the pitch is imposed only on the host association. In fact, it is not a duty of the guest organisation to have a doctor on the pitch, but only the right to request one. $^{25}$

A crucial question to be asked is whether a distinction between a professional athlete for whom the professional sport act shall apply, and a professional de facto athlete for whom general employment law shall be applicable, could be justified. In this case, the answer should be rather negative. In fact, the question can be raised as to what the difference is between a basketball player and a volleyball player participating in the equivalent level of sporting competition, except that the first one is qualified by the correlative national sport federation as professional, while the second one is viewed as an amateur. Such differential treatment appears unjustifiable, because of the need to consider the facts which should prevail over the formal qualification of the Italian sports federations.

Also, the difference in the treatment between professional athletes and professional de facto sportsmen appears in contrast with the regulations set up by the international sports federations. In this regard, reference may be made with the FIFA regulations on the status and transfer of players, which underline that: 'A professional is a player who has a written contract with a club and is paid more for his footballing activity than the expenses he effectively incurs. All other players are considered to be amateurs. ${ }^{26}$

A more specific question to be asked is whether a professional (also de facto) athlete needs special protection of health, in comparison to other workers. It this case, the answer should be in the affirmative. The absence of specific rules cannot be properly replaced by the application of the ordinary employment contract, because

23 To investigate the issue of the obligations provided for protection of athletes, wich are imposed on professional sport organisations, see, among others, F. Briguglio, 'La tutela sanitaria delle attività sportive', in C. Bottari (eds.), Attività motorie e attività sportive: problematiche giuridiche, Padova, Cedam, 2002, 159; G. Agrifoglio, La responsabilità del medico sportivo, Torino, Giappichelli, 2010, 74; G. Pacifico, 'L'idoneità alla pratica sportiva agonistica e non agonistica: normativa nazionale di riferimento', in C. Bottari, R. Nicolai and G. Pacifico (eds.), Sport e sanità, Bologna, Bononia University Press, 2008, 87.

24 Art. 66(1)(f) of the internal organisational regulations of FIGC (Norme organizzative interne della Federazione Italiana Giuoco Calcio).

25 Art. 66(1)(b) of the internal organisational regulations of FIGC.

26 Art. 2(2) of the regulations on the status and transfer of players of FIFA. 
the athletes need a more stringent form of health care protection. This leads to an issue of discrimination in health care protection.

In other terms, when it comes to the sport, some behaviors that are prohibited in the majority of employment relationships are instead permitted. This circumstance is justified by the social value of sport. Otherwise, many different sports would be forbidden. The risks that such activities may carry require a way to ensure the special protection of the health of athletes, which best fits the needs of the sports sector. Nevertheless, leaving the decision regarding the measures to be taken for the health protection of sportsmen to the discretion of sports federations does not appear to provide appropriate safeguards for the athletes. In fact, it is inadvisable that such determinations are adopted by the association of undertakings (sports federation) ${ }^{27}$ which are burdened by the health care protection costs. Besides, the protection of health is a fundamental right, which requires the participation of the legislator. Indeed a potential 'protection gap', which may depend on the choices of the sports federations, could be based on economic reasons, and shall not be permitted in the sports sector.

Along the same line of thought, it may be argued that an issue relating to the constitutionality of Article 2, Act No. 91/1981 could be raised under the provisions of Articles $3^{28}$ and 32 of the Italian Constitution. ${ }^{29}$ It is not justifiable to introduce distinctions in identifying the needs relating to health care that are not based on the factual reality, but on hypothetical assessments (by the sports federations) on the economic and social importance of an activity. ${ }^{30}$ However, for a long time, a

27 European Court of First Instance, 26 January 2005, T-193/02, Laurent Piau v. Commission of the European Communities, European Court Reports 2005 II-00209, paragraph 4, which states: 'The Federation internationale de football (FIFA) constitutes an association of undertakings within the meaning of Article 81 EC.'

Art. 3 of the Italian Constitution states: 'All citizens have equal social dignity and are equal before the law, without distinction of sex, race, language, religion, political opinion, personal and social conditions. It is the duty of the Republic to remove those obstacles of an economic or social nature which constrain the freedom and equality of citizens, thereby impeding the full development of the human person and the effective participation of all workers in the political, economic and social organisation of the country.'

Art. 32 of the Italian Constitution declares: 'The Republic safeguards health as a fundamental right of the individual and as a collective interest, and guarantees free medical care to the indigent. No one may be obliged to undergo any health treatment except under the provisions of the law. The law may not under any circumstances violate the limits imposed by respect for the human person.'

To explore the question of the right to health, such as primary and fundamental right, see, among others, F. D. Busnelli, 'Diritto alla salute e tutela risarcitoria', in F. D. Busnelli and U. Breccia (eds.), in Tutela della salute e diritto privato, Milano, Giuffrè, 1978, 534; M. Bessone and E. Roppo, 'Diritto soggettivo alla salute, applicabilità diretta dell'art. 32 della Cost. ed evoluzione della giurisprudenza', Politica del Diritto 1974, 766; C. Bottari, 'La tutela della salute tra solidarietà e sussidiarietà', in C. Bottari and L. S. Rossi (eds.), Sanità e diritti fondamentali in ambito europeo ed italiano, Rimini, Maggioli, 2013, 25; M. Franco, Diritto alla salute e responsabilità civile del datore di lavoro, Milano, Franco Angeli, 1995, 133; R. Carmina, "L'obbligo degli enti sportivi dilettantistici di tutelare la salute degli sportivi e i correlativi profili di responsabilità", Responsabilità Civile e Previdenza, 2015, 332; L. Mengoni, 'La tutela giuridica della vita materiale nelle varie età dell'uomo', Rivista 
part of the jurisprudence denied the fact that professional de facto athletes could be assimilated to professional athletes in terms of health protection. In this sense, the Tribunal of Naples stated that, in case an athlete got injured in the course of a game, the absence of a doctor does not imply liability on the part of the relevant amateur football association. In fact, the amateur football association would not have a duty of care (this would only concern the event organiser (sports association hosting the event)), and the lack of an employment contract would also make it impossible to infer contractual liability. ${ }^{31}$ Anyway, the courts have changed their orientation over time. The recent judgment of the Court of Cassation argued that 'the sporting organizations are obliged to protect the health of athletes, also through the prevention of detrimental events to their mental and intellectual integrity'. Such liability, for the court, derives from Article 2049 of the Italian Civil Code ${ }^{32}$ and from Article 32 of the Italian Constitution. This judgement also states that 'a sport [amateur] tournament based on the competition between the participants (...) that involves a greater psychophysical effort for the purpose of prevalence of one team over another cannot (...) be considered as not competitive'. ${ }^{33}$ Following this line of thought, a focus on providing greater athlete protection supports the use of the contractual liability. In fact, the Tribunal of Genova recognised the existence of contractual liability on the part of the amateur sports organisation in the case in which a black belt holder caused injuries to a student, during an exhibition of karate. It was argued that the amateur sports association 'has the duty (...) to protect the physical safety of students and to prevent the sports situation which goes beyond the boundaries of the natural risk'. ${ }^{34}$ In the light of the above mentioned considerations, it may be argued that the right to perform a sporting activity has to be understood as the explication of the right to health, which includes among its attributes ongoing medical care for athletes. Another reality is that Article 32 of the Constitution is a precept not only addressed to the public authorities, but also to the private entities, and configures the right to health as a fundamental right, qualified as a subjective position inherent to the primary values of the person that cannot be compromised in its primary contents, because it is a direct reflection of the right to life. ${ }^{35}$ In addition, if the lack of adequate legal

trimestrale di diritto e procedura civile 1982, 1117. Contra P. Pecinovsky, 'Roken in de gevangenis: recht op gezondheid haalt het niet van het privacyrecht', Nieuw Juridisch Weekblad 2015, 448. Tribunal of Napoli, 29 January 1996, www.grandiclienti.ilsole24ore.com.

32 Art. 2049 of the Italian Civil Code states: 'masters and employers are liable for the damage caused by an unlawful act of their servants and employees in the exercise of the functions to which they are assigned.'

33 Court of Cassation, section III, 13 July 2011, n. 15394, www.dirittoegiustizia.it.

34 Tribunal of Genova, 4 May 2000, www.grandiclienti.ilsole24ore.com.

35 The importance of full health protection results also from the Third Programme for the Union's Action in the Field of Health (2014-2020). In fact the first thematic priorities of it is: 'promote health, prevent diseases and foster supportive environments for healthy lifestyles taking into account the "health in all policies" principle'. Regulation (EU) No. 282/2014 of the European Parliament and of the Council of 11 March 2014 on the establishment of a Third Programme for 
provisions in professional de facto sport were to be interpreted as a restriction of health protection, it should be noted, that these sporting activities, although ideally aimed at the individual and collective welfare, are distorted, in the absence of appropriate safeguards, and turn into potentially risky practices detrimental to good health. It is surely defensible to state that the athlete should not become the victim of a complex system of the employment status in sport, in Italy. As the doctrine underlines, sport 'is (...) to be seen as a vehicle of personal fulfilment, physical and social well-being'. ${ }^{36}$

One can also raise a question of whether a distinction between amateurs as employees, and pure amateurs, is correct when it refers to health care protection. It appears that, in this case, the answer should be in the affirmative, because the more competitive the sport, ${ }^{37}$ the greater the risk to the health of athletes. Economic interests are clearly present in competitive sport, which is closely related to victory in sporting competitions, which can have an extremely negative effect on the health of athletes. In this situation, for example, the necessity of an immediate recovery from injury of the sportsman, must be considered. This does not mean that adequate provisions should not be provided for the protection of health of pure amateur athletes.

\section{FREE MOVEMENT OF WORKERS AND THE ITALIAN 'VINCOLO SPORTIVO'}

Another important difference between (real or only qualified as such) amateur sportsmen and professional athletes, which depends on the application of Act No. 91/1981, is the 'vincolo sportivo'. This Italian sporting institution means that when an athlete joins a new team, there an obligation to pay certain amount of money to the association of origin, even in the case that the contract has expired. The decision of the Court of Justice of the European Communities in the Bosman case stated that the rules of sport could not provide restrictions to the EU law on the free movement of workers. In other words, the decision of the European court declared this permanent sport contract as illegal, because it limited the freedom of sportsmen to be taken on by another company belonging to the same sport. ${ }^{38}$ This judgment has seen partial application in Italy, since it was considered applicable to the professional sector. As a matter of fact, this sentence was reflected only in Law No. 91/1981 on professional sport activity. In this regard, Article 16 of this particular Act provides 'the limitations

the Union's Action in the Field of Health (2014-2020) and repealing Decision No. 1350/2007/EC, Annex I, http://eur-lex.europa.eu.

F. Hendrickx, "Doping The athlete in an age of presumed innocence: what if the lawyer wins the race?", in B. Raymaekers (ed.), Lectures for the XXIst century 2008-2009, Leuven, Leuven University Press, 2008, 185.

37 Also the risk accepted by the athletes varies in relation to the sport that they practice.

38 Court of Justice of the European Communities, 15 December 1995, C-415/93, ASBL Union Royale Belge des Sociétes de Football Association, Royal Club Liegeois, Unione des Associations Européennes de Football UEFA v. Bosman, European Court Reports 1995 I-04921. 
to the contractual freedom of the professional athlete, identified as "vincolo sportivo" in current sports regulations, will be gradually eliminated over 5 years from the date on which this law comes into force, in accordance with the procedures and parameters established by the national sports federations and approved by CONI, in relation to the age of the athlete, and to the duration and financial content of the relationship with the club'. Also, Article 5 of Law No. 91/1981 prescribes that the expiry term of the employment contract cannot exceed 5 years (if it is not prolonged). In addition, the emended Article 6 of the Act states that a reimbursement for the training or coaching of a young athlete only has to be paid when the athlete signs his first ever professional contract with the sporting club that has provided training. Furthermore, this monetary reimbursement must be reinvested for sporting purposes. ${ }^{39}$ Thus, as the doctrine underlines, 'it has therefore became impossible for (professional) sport clubs to indefinitely and freely dispose of the exclusive rights that belong to the athlete himself'. ${ }^{40}$

However, the 'vincolo sportivo' for the amateur sport (both recreational and nonrecreational) still remains a part of the legal system. In other terms, the 'vincolo sportivo', which is still in force in the Italian legal system, is a sporting institution that operates in the amateur sports sector at the time of enrollment of athlete. It means that the club has both the right to use the player for performances, and the power to prohibit athletes from to providing their services for the benefit of other teams. Therefore, the athlete cannot play for another team, without the consent of the club of origin, which depends on the payment of a certain amount of money, which is arbitrarily established. However, many sports federations have set an age limit (usually 25 years), over which the athlete automatically becomes free from this constraint. This limitation must be evaluated positively. Nevertheless, the 'vincolo sportivo' concerns the years of greatest potential of the athletes' sporting careers. ${ }^{41}$

This Italian sporting institution might be warranted by the contractual autonomy because it depends on the voluntary nature of membership, and the correlative voluntary submission to this constraint. The principle is safeguarded by Article 2 of

39 Before the judgment of the European Court of Justice in the Bosman case the article 6 of the Law No 91 of 1981 prescribes that a sport club when transferring an athlete always had to pay reimbursement for the training and technical development of the athlete.

40 T.G. Foppen, "Italian Regulation of Sports and its Law n. 91 of 1981 - A Solution for Sports-Related Problems in The Netherlands?", The International Sports Law Journal, 2010, 87.

41 As an example of 'vincolo sportivo', see the discipline of soccer at the art. 40 of the Regulations of the national amateur league that establishes the existence of this sport institution for amateur athletes until they become twenty-five years old. In addition, articles 94 ter and 106 of the internal organizational regulations of FIGC lay down the possibility of release of young amateurs in specific cases. To investigate the issue see, ex multis, P. Moro, "Natura e limiti del vincolo sportivo", Rivista di diritto ed economia dello sport, 2002, 69; P. Moro, A. De Silvestri, E. Crocetti Bernardi and P. Lombardi, Vincolo sportivo e diritti fondamentali, Pordenone, Euro 92 Editrice, 2002, 1; E. Lubrano, "Vincolo sportivo pluriennale: verso una fine annunciata?", GiustiziaSportiva.it, 2005, 40; A. Scarcello and A. Tomassi, "Il tramonto del vincolo sportivo. Nota alla decisione del Tribunale di Venezia, giudice del lavoro, 13 Agosto 2009”, GiustiziaSportiva.it, 2009, 57. 
the Italian Constitution, underlining that 'the Republic recognizes and guarantees the inviolable rights of the person, both as an individual and in the social groups where human personality is expressed', and by Article 18, which provides that 'citizens have the right to form associations freely and without authorization for those ends that are not forbidden by criminal law'. It also could be justified in the context of independence of sport. This principle is recognised by Act No 280/2003 ${ }^{42}$ and by the EU White Paper on sport, ${ }^{43}$ as well as Article 165 TFEU. ${ }^{44}$ Other reasons which would make it permissible are the need to maintain a financial and competitive balance between clubs, the necessity to support the search for talented sportsmen and the training of young players at European level.

Nevertheless, there are arguments more relevant to this, which suggests its abolition. In order to be able to tackle the last two statements, we can refer to the judgment by the Court of Justice in the Bosman case, which states: 'the application of the transfer rules is not an adequate means of maintaining financial and competitive balance in the world of football. Those rules neither preclude the richest clubs from securing the services of the best players nor prevent the availability of financial resources from being a decisive factor in competitive sport, thus considerably altering the balance between clubs. ${ }^{45}$ Moreover, 'those fees are by nature contingent and uncertain and are in any event unrelated to the actual cost borne by clubs of training both future professional players and those who will never play professionally. The prospect of receiving such fees cannot, therefore, be either a decisive factor in encouraging recruitment and training of young players or an adequate means of financing such activities, particularly in the case of smaller clubs. ${ }^{36}$ Furthermore, as the Advocate General of this case pointed out, the same aims could be achieved at least as efficiently by other means. In particular, the Advocate General argued: 'it would be possible to determine by a collective wage agreement specified limits for the salaries to be paid to the players by the clubs and it would be conceivable to distribute the clubs receipts

42 Art 1, comma 1, of Act No 280/2003 prescribes the autonomy of the Italian sport order as a branch of the international sport order referring the IOC.

43 White Paper on sport, 11 July 2007. On the topic, see, among others, I. Blackshaw, “The specificity of sport and the EU White Paper on sport: some comments", International Sports law Journal, 2007, 88; J.A.R. Nafziger, "European and North American models of sports organization”, in J.A.R. Nafziger and S.F. Ross (eds.), Handbook on International Sports Law, Cheltenham, Edward Elgar Publishing, 2011, 87.

44 On the thematic, see, among others, B. Garcia and S. Weatherill, "Engaging with the EU in order to minimize its impact: sport and the negotiation of the Treaty of Lisbon", Journal of European Public Policy, 2012, 238; G. Pearson, "Sporting Justifications under EU Free Movement and Competition Law: The Case of the Football 'Transfer System”, European Law Journal, 2015, 220.

45 Court of Justice of the European Communities, 15 December 1995, C-415/93, ASBL Union Royale Belge des Sociétes de Football Association, Royal Club Liegeois, Unione des Associations Européennes de Football UEFA v. Bosman, European Court Reports 1995 I-04921, paragraph 107.

46 Court of Justice of the European Communities, 15 December 1995, C-415/93, ASBL Union Royale Belge des Sociétes de Football Association, Royal Club Liegeois, Unione des Associations Européennes de Football UEFA v. Bosman, European Court Reports 1995 I-04921, paragraph 109. 
among the clubs. Specifically, that means that part of the income obtained by a club from the sale of tickets for its home matches is distributed to the other clubs. Similarly, the income received for awarding the rights to transmit matches on television, for instance, could be divided up between all the clubs. ${ }^{47}$ Besides, a reasonable question is: 'What alternatives might there be in a system, such as that of a sport, where the freedom of choice is not guaranteed?' Actually, an athlete who wants to practice a sport at high level, can join only one sports federation. The sports federations and national Olympic Committees are the only entities that are able to guarantee real access to certain economic activities. As a matter of fact, such a system is based on the principle of a single federation for sport. In particular, the option of setting up an amateur league, alternative to the official monopolistic position of the sports federations, does not affect the substance of the issue. In fact, only the sports federations and the national Olympic Committees allow the access to the controlled sports and, along with it, to the official and internationally accepted sport titles that are really appealing because they are economically and socially expendable. ${ }^{48}$ The monopolistic structure of sport is also reflected in the rules that prevent athletes from exercising their professions freely, by providing disproportionate and unjustified obstacles to companies that want to organise alternative sporting events not linked to the sports federations. ${ }^{49}$

Additionally, it has been argued that the distinction between professional and amateur sport in Italy is based on a formal choice of the sports federation, which does not take into account the employment relationship between the club and the athlete. ${ }^{50}$ Consequently, the 'vincolo sportivo' provided in the amateur sporting arena, results in a potential violation of EU law on the free movement of workers. ${ }^{51} \mathrm{In}$ fact, as it is

47 Opinion of Mr Advocate General Lenz, 20 September 1995, C-415/93, ASBL Union Royale Belge des Sociétes de Football Association, Royal Club Liegeois, Unione des Associations Européennes de Football UEFA v. Bosman, European Court Reports 1995 I-04921. In this sense, for example, FIFA pointed to a cap for training compensation, see R. Blanpain, The legal status of sportsmen and sportswomen under international, European and Belgian national and regional law, The Hague, Kluwer Law International, 2003, 52. Compare also on training compensation R. Parrish, Sports law and policy in the European Union, Manchester, Manchester University Press, 2003, 148. F. Goisis, La giustizia sportiva tra funzione amministrativa ed arbitrato, Milano, Giuffrè, 2007, 151.

49 See, among others, the European Commission formal proceedings opens in relation to Formula One and other international motor racing series, 30 June 1999, http://europa.eu/rapid/press-releas, commented by S. Weatherill, “Fair Play Please!”: Recent Developments in the Application of EC Law to Sport', Common Market Law Review, 2003, 60 and 61; the European Commission formal investigation opens in relation to the International Skating Union's eligibility rules, 5 October 2015, http://europa.eu/rapid/press-release. Moreover, there are also some national laws that provide better tax treatment for the sports companies that are part of the official system. See, for example, the Italian Law No. 398 of 1991 that gives tax breaks to amateur sports clubs.

50 Of this opinion L. Musumarra, "La qualificazione degli sportivi professionisti e dilettanti nella giurisprudenza comunitaria”, Rivista di diritto ed economia dello sport 2005, 39.

51 See on the topic, among others, M. Colucci, "Free movement of persons within the European Union”, in R. Blanpain, M. Colucci and S. Sica (eds.), The European Social Model, Antwerpen Oxford, Intersentia, 2006, 151; R. Blanpain, European Labour Law, Alphen aan den Rijn, Kluwer Law International, 2012, 290; F. Hendrickx and S. Giubboni, "European Union labour law and the 
well known, Article 45 TFEU foresees that 'freedom of movement for workers shall be secured within the Union. Such freedom of movement shall entail the abolition of any discrimination based on nationality between workers of the Member States as regards employment, remuneration and other conditions of work and employment'. This Article has a horizontal effect, meaning that it is applicable not only to public authorities, but also to private organisations. ${ }^{52}$ Further, article 45 TFEU includes two principles: the no discrimination argument and the principle of market access. The no discrimination argument implies that the EU workers may not, in the territory of another Member State, be treated differently from national workers on grounds of nationality. A legal commentator claims that 'this requirement of equal treatment as regards pay and working conditions with the workers in the State of employment was not only inspired by concern about the social protection of migrant workers, but also by the wish to protect the Member States who might be willing to work for lower social conditions. ${ }^{53}$ Nevertheless, this is a secondary argument compared to the principle of market access, contained in Article 45(1) TFEU. ${ }^{54}$ In fact, the limitation of market access is also prohibited under the aforementioned Article, as the Court of Justice states, whereby 'they still directly affect players access to the employment market in other Member States, and are thus capable of impeding freedom of movement for workers ${ }^{55}$ or 'discourage that player from exercising his right of free movement'. ${ }^{56}$ In other words, 'provisions which, even if they are applicable without distinction, preclude or deter a national of a Member State from leaving his country of origin in order to exercise his right to freedom of movement therefore constitute an obstacle to that freedom. ${ }^{57}$ Even if it were considered that the limit of the principle of the free movement of workers consists in its application to the labour market, it should be acknowledged, in any case, that the EU qualification of workers is not formal, but is based on the performance of paid work. As the doctrine declares: 'the criteria for the

European Social Model: A critical appraisal”, in M.W. Finkin and G. Mundlak (eds.), Comparative Labor Law, Cheltenham - Northampton, Edward Elgar Publishing, 2015, 379.

52 Y. Hafner, "The right of free movement for EU nationals in Switzerland in the domain of amateur sport: CEP Cortaillod v Swiss Athletics”, Entertainment and Sports Law Journal, 2010, 5.

53 H. Verschueren, “The European internal market and the competition between workers", European labour law journal, 2015, 135.

54 See N. Countouris and S. Engblom, “'Protection or protectionism?' A legal deconstruction of the emerging false dilemma in european integration", European labour law journal, 2015, 28, for which "market access is not incompatible with the ETP (equal treatment principle), but actually builds on it".

55 Court of Justice of the European Communities, 15 December 1995, C-415/93, ASBL Union Royale Belge des Sociétes de Football Association, Royal Club Liegeois, Unione des Associations Européennes de Football UEFA v. Bosman, European Court Reports 1995 I-04921, paragraph 103.

56 Court of Justice of the European Union, 16 March 2010, C-325/08, Olympique Lyonnais SASP v Olivier Bernard and Newcastle UFC, European Court Reports 2010 I-02177, paragraph 35.

57 Court of Justice of the European Communities, 27 January 2000, C-190/98, Volker Grafv Filzmoser Maschinenbau GmbH, European Court Reports 2000 I-00493, paragraph 23. See also Court of Justice of the European Communities, 17 March 2005, C-109/04, Karl Robert Kranemann v Land Nordrhein-Westfalen, European Court Reports 2005 I-02421. 
existence of an employment contract are the duty to work; falling under the authority of someone and receiving remuneration for the work done', so 'an athlete with amateur status could well fall under the definition of a worker, given that the criteria for the existence of an employment contract are applicable to him or her'. ${ }^{58}$ For the Court of Justice 'it is important to note that the mere fact that a sports association or federation unilaterally classifies its members as amateur athletes does not in itself mean that those members do not engage in economic activities within the meaning of Article 2 of the Treaty', ${ }^{59}$ then, 'as to the concept of worker, it must be borne in mind that (...) it may not be interpreted differently according to each national law, but has a Community meaning. It must be defined in accordance with objective criteria which distinguish the employment relationship by reference to the rights and duties of the persons concerned. The essential feature of an employment relationship is that, for a certain period of time, a person performs services for and under the direction of another person, in return for which he receives remuneration' ${ }^{60}$ Otherwise, it would be paradoxical that the application of the EU law depends on formal statements of the sports federations, which would thereby become unconditional referees of the free movement of workers. Bearing in mind these considerations, the 'vincolo sportivo' results in a limitation of the principle of free movement of workers, which creates an unreasonable balance in the needs of European cohesion.

From the written question of 23 November 2009 stems the issue of legitimacy of 'vincolo sportivo' provided by the Italian Football Federation, which ties amateur footballers to their clubs up until the age of 25. In particular, the written question underlines the following: 'the FIGC - the only federation in the EU to do so - therefore continues to make provision for contractual ties for amateur footballers and is one of the few to do so for "young league players": in accordance with such tied contracts, the footballers are obliged (with no choice in the matter) to stay with their own teams, respectively up to the ages of 25 (amateurs) and 19 ("young league players"). This type of sports contract thus limits the free movement of the players, which is vital for the proper functioning of the internal market, and breaches competition rules given that it could potentially distort the market in football players. In the light of the above,

58 R.B. Martins, "Freedom of Movement in Relation to Sport", The International Sports Law Journal, 2007, 351-355.This author also state that: "in the amateur players example it is clear that the player is in fact carrying out the same work under the same conditions as players with an employment contract. In practice the rights of these amateurs are not being defended, although the amateurs might be considered as workers".

59 Court of Justice of the European Communities, 11 April 2000, C-51/96 and C-191/97, Christelle Deliege v. Ligue Francophone de Judo et disciplines associess ASBL e a, European Court Reports 2000 I-02549, paragraph 46.

60 Court of Justice of the European Communities, 13 April 2000, C-176/96, Jyri Lehtonen and Castors Canada Dry Namur-Braine ASBL v. Fédération royale belge des sociétés de basket-ball ASBL (FRBSB), European Court Reports 2000 I-02681, paragraph 45. See also Court of Justice of the European Communities, 18 July 2006, C-519/04, Meca Medina, Majcen v. Commissione CE, European Court Reports 2004 II-03291; European Court of First Instance, 26 January 2005, T-193/02, Laurent Piau v. Commission of the European Communities, European Court Reports 2005 II-00209. 
does the European Commission consider that such tied contracts are necessary to ensure that traineeships in the football world are protected? After the 1995 Bosman ruling, is it lawful to have rules which, in actual fact, restrict footballers in the exercise of some of their fundamental freedoms? Does the European Commission intend to check whether the NOIF rules are lawful and, should it be ascertained that they are not, to take any measures in the short term?'61 The European Commission replied that it intends to continue the analysis on the compatibility with EU law of the possible barriers that could emerge from the NOIF rules of the FIGC, by preventing the free movement of citizens and workers in the EU. This EU institution, in the aforementioned answer, also refers to the Bernard Case ${ }^{62}$ and prescribes that it could provide useful elements for the continuation of the analysis. ${ }^{63}$

However, it could be considered that in the Bernard Case the Court of Justice excused a measure that was an obstacle to the freedom of movement of workers. In fact, the Court declared 'in view of the considerable social importance of sporting activities and in particular football in the European Union, the objective of encouraging the recruitment and training of young players must be accepted as legitimate'. ${ }^{64}$ Effectively, this case law resembles the issue of 'vincolo sportivo' if we believe that, in both situations, the interest pursued is the development and training of young players. ${ }^{65}$ Anyhow, there is a crucial difference between these two cases. As a matter of fact, 'vincolo sportivo' implies that an indemnity should be paid for each transfer of the player, until he reaches a specified age. Instead, in the Bernard case, the player, at the end of his training with the club, is obliged to sign his first professional contract with that club - if the club requires him to do so. In this way, the club that trains the athlete may obtain a remuneration from the player transfer. This legal instrument shares some similarities with the duty present in the Italian system, to pay reimburse, for training or coaching a young athlete, the sports club that has provided the athlete youth training, only in the case that the athlete signs his first ever professional contract. In

61 Written question E-5813/09, 23 November 2009, by Iva Zanicchi (PPE), Roberta Angelilli (PPE), Amalia Sartori (PPE), Marco Scurria (PPE), Alfredo Antoniozzi (PPE), Paolo Bartolozzi (PPE), Salvatore Iacolino (PPE), Magdi Cristiano Allam (PPE), Licia Ronzulli (PPE), Potito Salatto (PPE), Lara Comi (PPE), Aldo Patriciello (PPE), Crescenzio Rivellini (PPE), Tiziano Motti (PPE), Sergio Paolo Frances Silvestris (PPE), Carlo Fidanza (PPE), Giovanni La Via (PPE), Salvatore Tatarella (PPE), Cristiana Muscardini (PPE), Erminia Mazzoni (PPE), Vito Bonsignore (PPE), Gabriele Albertini (PPE), Raffaele Baldassarre (PPE), Clemente Mastella (PPE), Giovanni Collino (PPE), Elisabetta Gardini (PPE), Antonello Antinoro (PPE), Herbert Dorfmann (PPE), Oreste Rossi (EFD), Gianni Pittella (S\&D), Patrizia Toia (S\&D), Gianluca Susta (S\&D) and Rosario Crocetta (S\&D) to the Commission, www.europarl.europa.eu.

62 Court of Justice of the European Union, 16 March 2010, C-325/08, Olympique Lyonnais SASP v Olivier Bernard and Newcastle UFC, European Court Reports 2010 I-02177.

63 Answergiven by Mr. Šefčovičon behalf of the Commission, 28 January2010, www.europarl.europa.eu.

64 Court of Justice of the European Union, 16 March 2010, C-325/08, Olympique Lyonnais SASP v Olivier Bernard and Newcastle UFC, European Court Reports 2010 I-02177, paragraph 39.

65 M. Colucci, R. Blanpian and F. Hendrickx, The Bernard case: Sport and Training Compensation, European Sports Law and Policy Bulletin, Bracciano (RM), Sports Law and Policy Centre, 2010, 1. 
both cases, all of this should mean that clubs will have to pay an amount of money at the time of the player's first transfer. In contrast, in the case of 'vincolo sportivo', as we anticipated, an amount of money is paid also to other clubs, other than the one which trained the player. Furthermore, with 'vincolo sportivo' the age (usually 25 years) at which the player can freely transfer from one club to another, is often when more than half of his sporting career is over. Consequently, the payment as regards the 'vincolo sportivo', is not related to the training of the players, but 'could be considered as a kind of non-competition clause between the various sports clubs'. ${ }^{66}$ As the doctrine states 'the transfer system (...) thus prevent clubs from developing their economic activity on the downstream markets' and 'works to the detriment of (...) players' since 'on expiry of his contract a club might offer a player poorer conditions because the club has the power of refusing consent to a transfer. That would particularly affect players to whom another offers the possibility of a more favorable contract'. ${ }^{67}$

In addition, closely analysed, the reasoning of the Court of Justice in the Bernard case, that also has value mutatis mutandis for 'vincolo sportivo', may be criticised because 'the calculation of the damages should correspond with real and actually incurred training costs' ${ }^{68}$, and should not be determined arbitrarily, as it is the case here. Finally, it should be noted that in the answer of the European Commission given to the written question on 'vincolo sportivo', it is possible to recognise an implicit assimilation between professional sport and professional de facto sport. As a matter of fact, the Bernard case concerns a professional sports issue. The European Commission compares it to the 'vincolo sportivo', which has relevance especially in the professional de facto sports sector. Thus, in this way, the European Commission assimilates them.

Also, although in theory the sports organisation of destination needs to pay the fee for the transfer of the player, in practice this responsibility often falls on the athlete. In this way, the 'vincolo sportivo' often impedes amateur athletes from changing teams, since they are unable to make the payment to the society or association of origin. In other words, the fee often ends up becoming a burden on the athlete himself, and thus creating a modern form of slavery, in which the athlete becomes the servant of the sports organisation, and the indemnity becomes a way of freeing himself of such subjection.

Furthermore, it should be noted that the 'vincolo sportivo' involves a kind of constraint of belonging, in addition to a restraint regarding performance, taking into consideration that the subject cannot move from one sporting organisation to another without the approval of the first. This would mean that the athlete loses his subjectivity, forfeits the opportunity to express his own desires, and becomes a sort of objective component of the sports organization, not dissimilar from any inanimate object.

66 T.G. Foppen, 'Italian Regulation of Sports and its Law n. 91 of 1981 - A Solution for Sports-Related Problems in The Netherlands?', The International Sports Law Journal, 2010, 87.

67 R. Blanpain, European Labour Law, Alphen aan den Rijn, Kluwer Law International, 2012, 329.

68 F. Hendrickx, 'The Bernard-case and training compensation in professional football', European Labour Law Journal, 2010, 397. 
It could be argued that 'vincolo sportivo' has the task of ensuring that amateur clubs receive the income they should. Notwithstanding, as the Court of Justice has argued: 'it should be pointed out (...) that a measure which constitutes an obstacle to freedom of movement for workers could be accepted only if it pursued a legitimate aim compatible with the Treaty and were justified by pressing reasons of public interest. But even if that were so, application of that measure would still have to be such as to ensure achievement of the aim in question and not go beyond what is necessary for that purpose. (...) aims of a purely economic nature cannot constitute pressing reasons of public interest justifying a restriction of a fundamental freedom guaranteed by the Treaty'. ${ }^{69}$ Therefore, it could be argued that the 'vincolo sportivo' is in contrast with the EU rules on the free movement of workers and also results in an irrational discrimination between amateur sport participants and professional athletes in the application of the EU provisions. So it is not clear how such a historical institution, which derived its justification from the rhetoric of free sport, can continue to contradict the dogmas on which EU law is based.

Further a question that could be asked, on the topic of legitimacy of 'vincolo sportivo', is whether the principle of the free movement of workers concerns also the real amateur sport participants. It seem that in this case, the answer should be in the affirmative. In effect, Article 45 of TFUE on the free movement of workers has expanded to include the principle of European citizenship. The Court of Justice prescribes that: 'every person holding the nationality of a Member State is a citizen of the Union'70 and 'the status of citizen of the European Union is destined to be the fundamental status of the nationals of the Member States', ${ }^{71}$ 'enabling those who find themselves in the same situation to enjoy the same treatment in law'. ${ }^{72}$ In addition, 'the right of citizens of the Union and their family members to move and reside freely within the territory of the Member States (...) must be interpreted as precluding national legislation (...) automatically - whatever the circumstances - bars the grant of a benefit'. ${ }^{73}$ As the doctrine argues 'a paradigm-shift has to be

69 Court of Justice of the European Communities, 17 March 2005, C-109/04, Karl Robert Kranemann $v$ Land Nordrhein-Westfalen, European Court Reports 2005 I-02421, paragraphs 33 and 34.

70 Court of Justice of the European Communities, 19 October 2004, C-200/02, Kunqian Catherine Zhu and Man Lavette Chen $v$ Secretary of State for the Home Department, European Court Reports 2004 I-09925, paragraph 25.

71 Court of Justice of the European Union, 20 May 2010, C-56/09, Emiliano Zanotti v Agenzia delle Entrate - Ufficio Roma 2, http://eur-lex.europa.eu, paragraph 68.

72 Court of Justice of the European Communities, 20 September 2001, C-184/99, Rudy Grzelczyk v Centre public d'aide sociale d'Ottignies-Louvain-la-Neuve, European Court Reports 2001 I-06193, paragraph 31 .

73 Court of Justice of the European Union, 19 September 2013, C-140/12, Pensionsversicherungsanstalt $v$ Peter Brey, European Court Reports 2013-00000, paragraph 81. On the topic see also Court of Justice of the European Union, 16 July 2015, C-218/14, Kuldip Singh and Others $v$ Minister for Justice and Equality, http://eur-lex.europa.eu; Court of Justice of the European Union, 23 February 2010, C-480/08, Maria Teixeira $v$ London Borough of Lambeth and Secretary of State for the Home Department, European Court Reports 2010 I-01107; Court of Justice of the European Union, 
detected from a selective and category-based model of "market solidarity" to the recognition of a "transnational personal status", which establishes a general claim of social integration in the member state of the Union in which the European citizen freely decides to move to, not unlike what happens in federal-policies'. ${ }^{74}$ Thus, it appears that 'vincolo sportivo' cannot be applied also to the amateur recreational sports sector, because it worsens the living conditions of EU citizens in Member States, and limits the right to move and reside freely in the Member States. In this sense, the online Summaries of EU legislation called the 'Free movement of Sportspeople' states that 'the right to free movement is one of the most important rights guaranteed by the European Union (EU) to its citizens. This right also applies to sportspeople, both professional as well as amateur. Consequently, any direct discrimination based on nationality or any unnecessary or disproportionate indirect discrimination and other obstacles that hinder the right to free movement of sportspeople are prohibited by EU law'. ${ }^{75}$

\section{CONCLUSION AND POSSIBLE SOLUTIONS}

In the light of the previous considerations, it should be noted that despite the judicial investigation into relationships in the sports sector, which aimed to identify indicators of an employment relationship and to allow the application of the principles of the employment contract, there still remain two obstacles to a practical assimilation between professional and professional de facto athletes. On one hand, there is an unreasonable distinction made between persons who are in the same position and depend on the application of a general employment contract instead of the sports employment contract, with, among other things, a correlative limitation to health protection. On the other hand, there are the consequences, in terms of violations of the EU law on the free movement of workers, resulting from the 'vincolo sportivo'.

In order to remedy this situation, which is detrimental to the rights of professional de facto athletes, some of the legal commentators have argued that the sports employment contract should be directly applied to the amateur, non-recreational sector, ${ }^{76}$ while other authors prefer to use an analogical argument. ${ }^{77}$ However, it

8 March 2011, C-34/09, Gerardo Ruiz Zambrano v Office national de l'emploi (ONEm), European Court Reports 2011 I-01177; Court of Justice of the European Union, 2 March 2010, C-135/08, Janko Rottman v Freistaat Bayern, European Court Reports 2010 I-01449.

74 F. Hendrickx and S. Giubboni, 'European Union labour law and the European Social Model: A critical appraisal', in M.W. Finkin and G. Mundlak (eds.), Comparative Labor Law, Cheltenham Northampton, Edward Elgar Publishing, 2015, 383.

75 Summaries of EU legislation, Free movement of sportspeople, http://eur-lex.europa.eu.

76 Ex multis, F. Realmonte, 'L'atleta professionista e l'atleta dilettante', Rivista di diritto sportivo 1997, 374 .

77 Among others, P. Ichino, 'Il lavoro subordinato: definizione e inquadramento, art. 2094-2095', in P. Schlesinger (ed.), Commentario al codice civile, Milano, Giuffrè, 1992, 183; L. Mercuri, 'Sport 
may appear somewhat paradoxical that Act No. 91/1981 can be subject to a direct or an analogical application, given that this regulation is a piece of exceptional legislation (lex specialis). In fact, it derogates from the general principles relating to employment, and therefore cannot be subject to the above mentioned applications. ${ }^{78}$ In this sense, it should be noted that the sports employment relationship has features that are contrary to the general principles applicable to an ordinary employment relationship. Consider, for example, the duration of it, the need to carry out continuous investigations on the physical condition of the athletes, the particular procedure for the imposition of disciplinary sanctions, the inapplicability of the rules which prohibit the demotion and the use of audiovisual equipment, and the non-usability of the provisions on individual dismissal in contracts of an indefinite duration. In addition, Act No. 91/1981 seems to prohibit the direct or analogical extension of its discipline to the amateur sports sector, taking into account its precise titling (rules for relationships between the company and professional sportsmen) which expressly limit the scope of its provisions to professional athletes. Furthermore, Article 2 of Act No. 91/1981 provides that the qualification of a sporting activity as professional depends on a choice of the relevant sports federation. In this sense, the Court of Cassation has denied, on several occasions, that Act No. 91/1981 can be extended directly, or by analogical application, to cases that are not included in its scope, given the fact that it is characterised by the presence of significant exceptions to the general discipline of employment. ${ }^{79}$ Consequently, it is surely defensible to state that the employment contract cannot be applied to professional de facto sport athletes. Furthermore, Article 2 of Act No. 91/1981 was not meant to allow the private sports federations to choose between the professional and amateur sports sectors, in the absence of a determination of guiding criteria by CONI (the public entity). However, this guiding criteria was not adopted because CONI has remitted this power to the statutory autonomy of sports federations. ${ }^{80}$ For this reason, the choice of sports federation has an integrative function of the law that was not foreseen for it. In other words, the decision of the sports federations, mentioned in Act No. 91/1981, should be a specification of the legislative provisions and of the guidelines of CONI. What can also be noted is that, sports federations do not even take into account the general principles established by Article 2 of Act No. 91/1981 (continuity and

professionistico (Rapporto di lavoro e previdenza sociale')', Novissimo digesto italiano, Torino, Utet, 1987, 516; P. Tosi, 'Sport e diritto del lavoro', Argomenti di diritto del lavoro 2006, 721. 
remuneration of the sporting activity), and thereby, they make choices which are manifestly unlawful. In fact, it should be noted that the discretion on the part of the sports federations cannot go beyond certain limits or it could potentially infringe upon basic human rights, such as health.

In conclusion, it is surely defensible to state that the disapplication of the decisions of the sports federations, relating to the nature of sport, seems necessary, taking into account consideration of their arbitrary character. Otherwise, it seems plausible that Article 2 of Act No. 91/1981 is unconstitutional and contrary to the fundamental principles of the European Union, as it allows the sports federations to make a fully discretionary choice that may result in differential treatment between professional and amateur athletes, when they both practice a sport with the same characteristics. In addition, it does not appear appropriate to qualify an amateur, non-recreational relationship as an employment contract, and it is necessary to resort to legal actions and correlative juridical decisions that are made on a case-by-case basis. Indeed, it seems sustainable to propose the introduction of a law, a law which provides an economic point, beyond which the indemnity paid is not a refund, but a gain that, thus, should involve the qualification of the sporting relationship as professional. ${ }^{81}$ Finally, it may be argued that the distinction between professional and professional $d e$ facto sport athletes seems to be a relic of the past that is no longer required in modern society. In fact, it conflicts with the principle of equality, restricts the right to health and violates the EU law on the free movement of workers.

81 See, for example, Art. 9 of Belgian Act on Professional Athletes, 24 February 1978, which qualifies a professional athlete as 'someone who takes up the obligation to prepare himself or to participate in a sport competition or sport exhibition, under the authority of someone else and remunerated with a salary which exceeds a certain amount'. Every year the norm on wage is fixed by a Royal Decree. 